Discussion Paper No. 788

\title{
ANALYSIS OF COUNTRY OF ORIGIN LABELING FOR FOOD PRODUCTS IN TAIWAN USING AUCTION EXPERIMENT
}

\author{
Wen S. Chern \\ Huei-Ching Lin
}

August 2010

The Institute of Social and Economic Research

Osaka University

6-1 Mihogaoka, Ibaraki, Osaka 567-0047, Japan 


\title{
Analysis of Country of Origin Labeling for Food Products in Taiwan using Auction Experiment
}

\author{
Wen S. Chern* \\ Huei-Ching Lin
}

\begin{abstract}
The purpose of this study is to evaluate the economic benefits of country of origin labeling (COOL) regulation by estimating the consumer's willingness to pay (WTP) for Taiwan products vs. other imported products if clearly labeled with their countries of origin. We employ the Vickrey second-price sealed bid auction and conducted auctions in three major cities in Taiwan in 2009. Charcoal-smoked plums from Taiwan and China and oolong teas from Taiwan, China, and Vietnam are auctioned products. One important feature of our experimental design is to investigate the impacts of product tasting on bidding behavior. We estimated Tobit bid models and the OLS premium functions. The regression results show that product tasting affected the participants' WTP positively or negatively depending on products. Specifically, tasting raised bids for Taiwan and China teas, but lowered bids for Vietnam tea. The econometric results show very high premiums for Taiwan products, ranging from $83 \%$ to $109 \%$ for tea and $55 \%$ to $66 \%$ for charcoal-smoked plum. These findings clearly show strong preference of Taiwanese consumers over food and agricultural products produced domestically. It is very important to have rigorous COOL regulation in Taiwan. If all foods and agricultural products are clearly labeled with their countries of origin, Taiwanese consumers and food producers stand to benefit greatly with COOL. The COOL would be one of the best instruments to reduce the negative impacts of agricultural trade liberalization under WTO or ECFA.
\end{abstract}

Key Words: Auction Experiment, Country of Origin Labeling, Tobit, Willingness to Pay, Bid Premium, Taiwan, China, Vietnam, Tea, Plum, Import, Food.

JEL Classifications: Q13, D12.

Acknowledgements: This study was sponsored by the National Science Council (NSC) in Taiwan. This draft was completed when Wen S. Chern was Visiting Foreign Scholar at the Institute of Social and Economic Research, Osaka University, Japan. The authors would like to thank Charles Horioka and other members of the Institute for their helpful comments when the paper was presented at the Institute on July 14, 2010.

\footnotetext{
*Corresponding author: Department of Economics, National Chung Cheng University, 168 University Road, Ming-Hsiung, Chia-Yi 621 Taiwan (chern.1@ccu.edu.tw).
} 


\section{Introduction}

The objective of this study is to evaluate the economic benefit of enforcing the country of origin labeling (COOL) regulation for food products in Taiwan. Specifically we use an auction experiment to quantify the willingness to pay (WTP) for food products produced in Taiwan vs. those imported from other countries. Our experimental auction design includes a special feature on product tasting. The study is motivated by two observations. First, many agricultural products imported or smuggled from China and other Southeast Asian countries are sold as though they are locally produced in Taiwan. For example, more than $70 \%$ of preserved fruits consumed in Taiwan are imported from other countries. Unfortunately most of retailers would never mention truthfully the country of origin for the products from China and other Southeast Asian countries. In the case of oolong teas imported from China and Vietnam, they are sold almost entirely with the name of Taiwan oolong tea in the market place. Merchants of those imported products gain unfair profits from not telling the consumer about the country of origin. Consumers are, of course, the losers in this market situation because they purchase fake products and in many cases they are harmful products. One reason why many consumers would not purchase agricultural products from China and other Southeast Asian countries is due to food safety concerns. The China milk power (melamine) scare happened in September 2008 has instilled fear in consuming foods from China.

The second observation is that Taiwanese consumers have reached the same level as those in Japan, Australia and the United States with a strong preference for food products produced domestically. Therefore, the economic benefits from COOL can be expected for domestically produced food products. But the question is how much the benefit would be?

The COOL is one approach to eliminate the asymmetry of information between the sellers and buyers of food products. This is particularly important due to the growing concerns on food safety. Knowing the true country of origin for food products, the consumer can decide on whether or not to purchase without such uncertainty. In order to protect the 
consumer, many developed countries have enforced mandatory COOL regulation. Japan has one of the most comprehensive COOL regulations, covering both fresh and processed food products. Japanese government requires for domestically produced products, particularly sea food products to label the place of origin as well. In addition, for processed products, the COOL is also required for the main ingredients used in the processed foods. The United States enacted its first mandatory COOL in the 2002 Farm Bill and began enforcing its COOL law for sea food products in 2005. By September, 2008, all meats, fresh and frozen fruits and vegetables had to have COOL. Today, if you go to the supermarkets in the U.S., Japan, Australia and New Zealand, you will find all fresh fruits and vegetables have clear and visible country of origin labels. All the meats and seafood products are packed with a clear COOL as well.

In Taiwan, the government enacted the first COOL regulation for packaged foods in January 2008. However, this requirement is waived if the package label already contains the manufacturer's address which shows sufficient information on the country of origin. This COOL regulation was further expanded to cover the imported bulk food products in 2010 . There seems not much enforcement to these COOL laws in Taiwan as no cases of violation have been reported. The consumer still does not know the country of origin for many products they purchase in Taiwan. This study attempts to demonstrate that Taiwanese consumers incur economic loss if the government's COOL regulation goes without strict enforcement. The results from this study would provide tangible estimates of the economic benefits from forcefully implementing the COOL regulation in Taiwan.

\section{Literature Review}

Since the legislation of the COOL regulation in the 2002 Farm Bill in the U.S., there have been several studies on the impacts of the mandatory COOL on consumers and producers of various agricultural products. Earlier Schupp and Gillespie (2001) conducted a 
telephone survey of food handlers and restaurants to investigate the consumer's attitude toward COOL. Their results show that $80 \%$ of respondents supported a mandatory COOL, but there was no indication about whether consumers were willing to pay for the additional cost. Loureiro and Umberger (2003) used data from a survey on the COOL for beef of food shoppers in grocery stores in Colorado, United States. Using a five-point Likert scale, they found that the most important attributes for beef are freshness (4.74), food safety (4.61), and high quality (4.4). Their Logit model showed that consumers were willing to pay an average of 38\% and 58\% premium for the "U.S. Certified Steak” and "U.S. Certified Hamburger," respectively, over those without the COOL.

Umberger et al. (2003) used a forth-price sealed bid auction experiment and a contingent valuation (CV) survey to estimate the WTP premiums for steaks with COOL. Their results show that the U.S. consumers were willing to pay a 19\% premium for the steak labeled with "USA guaranteed, born and raised in the U.S.” compared with those without COOL which was higher than the $11 \%$ premium estimated from the CV data. There was particular attention on meat products in the U.S. because of the debates on American consumers' preferences on domestic vs. imported meats, especially beef before the Congress passed the law to implement COOL for meat products in 2007.

The COOL not only affects the consumer, but also the supply side. The implementation of COOL requires a rigorous traceability system of food products through the entire marketing channel. This requires record keeping and auditing which would incur additional costs. The Agricultural Marketing Service of the U.S. Department of Agriculture estimated the record-keeping costs for all the affected sectors associated with COOL to be about $\$ 2$ billion (in U.S. dollars). VanSickle et al. (2003) argued that mandatory record-keeping at the producer level is not required and estimated the costs for record keeping for the rest of the supply chain to be between $\$ 70$ to $\$ 193$ million (in U.S. dollars). Hayes and Meyer (2003) estimated the cost of implementing COOL for the U.S. pork industry to be just over $\$ 1$ billion 
(in U.S. dollars), based on the trace-back systems used in the European Union. Focusing on the impacts of COOL on producers, Brester et al. (2004) found that with COOL, the retail prices of the U.S. produced beef and pork would increase by $4.05 \%$ and $4.45 \%$, respectively. Lusk and Anderson (2004) took the cost of COOL into account and analyzed its impact on producer and consumer welfare. Because of substitution effect, the poultry sector in the U.S. which COOL requirements are not applied to will be the only beneficiary if the producers of meat products have to bear half or more of the cost. However, the COOL would likely raise the demand for domestic products due to consumer preference. Their results show that an increase in aggregate consumer demand of $2 \%$ to $3 \%$ for American beef and pork is likely sufficient to offset any lost producer welfare due to the increased COOL costs.

Implementation of COOL regulation in one country may affect the demand and supply situations in another country. In a study conducted in Canada, Rude et al. (2006) showed that COOL will do little to help U.S. consumers, producers or processors. This is because U.S. packers are unlikely to slaughter pigs of Canadian origin due to segregation costs. However, Canadian producers stand to suffer significant losses under COOL, but Canadian consumers gain modest benefits through lower pork prices. Of course, under any public policy such as COOL, there are likely losers and winners. In the case of Canadian pork, there may not be strong preference for American pork over Canadian pork by U.S. consumers. Therefore, there will not be significant gains for American consumers under COOL. However, the situation is different in Taiwan where the preference differential between domestically produced food products and those imported form China and other Southeast Asian countries is apparent. Our study will not address the supply side or cost issues. However, the high price premiums for Taiwan produced products demonstrated in this study would make the resulting cost increase relatively trivial.

This study employs an auction experiment to estimate the willingness to pay (WTP) premiums for food products produced in Taiwan vs. those imported from other countries. As 
mentioned before, since many imported food products have been sold in Taiwan as though they were domestically produced, the clearly labeled products with COOL are not available in the market place. Thus we have to use the methods of valuation similar to those used for non-market goods. Food safety is a non-market good because you can not purchase food safety alone. Labeling for country of origin (COOL) or genetically modified (GM) foods is related to food safety. The two most widely used methods for valuating the economic benefits of food safety is contingent valuation method (CVM) and auction experiment. The CVM is based on hypothetical market created in a consumer survey questionnaire (Mitchell and Carson, 1989; Habb and McConnell, 2002). It has the advantage of collecting a large representative sample, but has been criticized for the likelihood of overestimation of WTP resulting from hypothetical bias. Auction experiment has gained its popularity in recent years as an alternative to the CVM in non-market good valuation. The most widely recognized advantage of the auction experiment is its close resemblance of a real market, rather than a hypothetical market. With auction, the winner of the auction has to buy the auctioned goods in the experiment. This method has been widely applied to the valuation of genetically modified (GM) foods (Huffman et al., 2003) and quality differentiated products (Umberger and Feuz, 2004).

There are several auction mechanisms used for experimental auctions (Lusk and Shogren, 2007). The most popular method is the Vickrey second-price sealed-bid auction. Vickrey (1961) suggested this method since it is easy to implement and it is a weakly dominant strategy for the participants to reveal their true valuations. Under this method, the highest bidder wins the product, but pays only the second highest bid. It has been shown that using this second-price auction, there is absolutely no advantage to bid anything other than your true WTP value. However, it has been observed that in the second-price auction, low bidders may feel inconsequential and thus become non-participatory bidders. Therefore the low bidders may not care about how they bid, affecting the accuracy of the auction results. In 
order to correct this problem, the uses of $4^{\text {th }}$ price, fifth price and nth price auction have been suggested (Shogren et al., 2001, Hoffman et al., 1993). These auction formats are of course more cumbersome to conduct and sometimes create confusion among the participants. Note that this study focuses on the impact of tasting in our experimental design. The tasting not only adds complexity in the design of experiment, but also requires additional time in the experiment. Therefore, we adopt the Vickrey’s second-price sealed-bid auction for this study.

Another important issue for doing auction experiment is about the repeated trials. Researchers often conducted repeated trials with one binding trial chosen randomly after all trials completed. With repeated trials one can gain additional observations. Since the sample size is often small relative to other CV surveys, we can attain more samples from repeating several rounds of auction in the experiment. The usual justification is for participants to receive market experience in order to understand that sincere bidding is a weakly dominant strategy (Coppinger et al., 1980) and to gain familiarity for valuating unfamiliar products (Shogren et al., 2000). Furthermore, we often announce auction results such as the ID of the highest bidder and the second highest bid after each trial. This practice helps participants to form a more accurate bidding price for the auctioned product. List and Shogren (1999) found that posting second price had some effect on bidding prices but by a small percentage and it does not affect the behavior of experienced bidders or the bidders of familiar products. They further found that anticipated strategic behavior wanes after two trials. Corrigan and Rousu (2006) found that there exits affiliation between trials when posting second price in each trial. Thus, they recommend valuation of bid premium to be more accurate than WTP. We adopt the use of repeated trials because there is no decisive evidence that repeated trials are not consistent with the demand revealing property.

\section{Experimental Auction Design}

A sound experimental auction design is extremely important for the success of an 
auction experiment. This task includes product choice, selection of auction mechanism, design of the step-by-step auction instruction, and development of survey questionnaire to collect important information about personal and demographic data, the participant's food purchasing behavior and risk perception. Since this study focuses on the impact of product tasting, it is important to develop a procedure on how and when to offer tasting during the experiment. Also it is important to decide on the locations of the experiment and how to recruit participants.

First task is about product choice. We selected two products for the experiment: charcoal-smoked plum and oolong tea. The reason for choosing these products was because of the recognition by Taiwanese consumers about the common practice of selling the imported preserved fruits and tea as Taiwan products in the market place over the years. We conducted a search on the United Daily News databank and found that there were 87 news articles reporting contaminated tea from Vietnam during January 2005 to August 2008. Much of these Vietnam teas actually came from China. Note that one important attribute for the auctioned product originated from different countries is that they have to look very similar. If they do not look alike, then it would be difficult to separate the effect of COOL on WTP from other product attributes such as color or shape. We used charcoal-smoked plums from Taiwan and China because they looked very similar. Due to time constraint, we dropped candy bar auction as a learning session in this experiment.

We maintain one very important principle for conducting auction experiment and that is we must use authentic products unlike other studies which used fake products. It would be unethical to auction the same product and then lie to the participants by labeling it with Taiwan and China untruthfully. We run into some difficulty to obtain plum and tea from China and Vietnam because almost all merchants would not admit that their stores sell plum or any other preserved fruits from China or oolong tea from China or Vietnam. With efforts and persuasion, we were able to convince one wholesaler of preserved fruits and one tea 
retailer to help us obtain the authentic products. They claimed that they asked friends from other stores to provide these products.

Note also that tea is a relatively expensive good. The extremely good oolong tea may cost several thousands of New Taiwan (NT) dollars per Gin (600 grams) a unit used for purchasing food products in Taiwan. In order to prevent the situation of insufficient budget for participants, we auctioned both plums and teas for only 150 grams or 1/4 Gin. Since participants were given $\$ 1,000$ (in NT dollars, or equivalently US\$32), they would have ample budget to bid on the auctioned goods.

Regarding the choice of auction mechanism, we conducted preliminary experiments to compare the second price and the $5^{\text {th }}$ price auctions, using student subjects from the National Chung Cheng University. These experiments showed very similar results. Therefore, we decided to use the second- price sealed-bid auction for this study.

Our next design task is about the repeated trials and product tasting. In order to provide participants with learning experience, we decided to have three trials of auction before product tasting and another three trials after tasting. We auctioned two products in the same experiment. In order to avoid telling people before hand about tasting, we first had three trials for charcoal smoked plum and then auctioned oolong tea for three trials. Then we had participants tasting the three oolong teas. After tasting, we had three trials of tea auction. Then we let participants tasting two plums and finishing the last three trials of plum auction. In this way, participants would not know there will be product tasting during the first three trials for both plum and tea.

In order to gain representativeness of this study, we conducted our experiments in three major cities in Taiwan: Taipei, Taichung and Kaoshiung. Due to research budget constraint, we recruited only 40 participants in each city. Two sessions were conducted in each location. Since after each auction we had to manually collect the bidding cards and sort out all the bids from the highest to the lowest, it was time-consuming. Therefore, 20 participants in each 
session seemed an optimal number. For recruiting, we posted the advertisement in many websites including the most visited BBS and other job search websites. In the advertisement, we indicated the date/time of the auction, and the number of participants in each categories specified by sex, age and education level according to Taiwan's recent demographic data (Ministry of Interior, Taiwan, 2009). Of course, those who saw the advertisement were young internet users and mostly ineligible for our experiment. However, they recruited for us their family and friends. Even though our sample is not truly random, but they reflect the current population mix. With $\$ 1,000$ cash payment, there were many people registered for the experiments. In fact we selected 40 persons from 121 registered for Taipei sessions, 142 persons for Taichung sessions and 208 for Kaoshiung sessions, representing acceptance rates of $33 \%$, $28 \%$ and $19.2 \%$, respectively.

The final section of the instruction is a questionnaire to collect data on the participant's food purchasing behavior, risk perception, food safety concerns, personal and demographic data. For example in the questionnaire, we asked participants to rank the relative importance between freshness and safety, between price and safety and between price and COOL when doing food purchase. The complete instruction for our auction experiment is available upon request.

\section{Auction Results}

The auction was conducted first in Taipei on February 27, 2009, then in Taichung on March 9 and Kaoshiung on March 13. Before these sessions, we also conducted a test auction at National Chung Cheng University for the focus group of nine food shoppers (not students) on February 25, 2009. Furthermore, we also conducted six sessions of the auction of candy bars and charcoal-smoked plums with student subjects in December 2008. In this study we used only the data collected from the public auctions. We had totally 116 participated in the sample from public auctions. 
Table 1 shows average bids by trial before and after tasting for charcoal-smoked plums from Taiwan and China. Note that we told the participants about where these plums came from in the beginning of the auction. Therefore, Trials 1-3 reflect the participant's valuation of their WTP knowing the country of origin while Trials 4-6 reflect their valuations after they had a chance to taste the products. Clearly the participants valued Taiwan plum higher than China plum as the average bid was \$ 52.16 per 150 grams for Taiwan plum and \$ 29.78 for China plum before tasting. Interestingly after tasting, the average bid for China plum increased to $\$ 41.32$ while the average bid for Taiwan plum also increased to $\$ 58.9$. Before tasting, the bid premium for Taiwan plum over China plum was \$22.38 while after tasting, this premium reduced to $\$ 17.58$. Clearly Taiwan plum was much preferred by the participants over China plum. Furthermore, product tasting did affect the participants' valuation of their WTP.

It was noted that China plum tasted more juicy than Taiwan plum. As part of the questionnaire, we asked participants about what kind of plum they like after tasting. With total sample, $47 \%$ liked Taiwan plum the best, $45 \%$ liked China plum, $7 \%$ indicated no difference between the two while $1 \%$ giving no opinion. Despite many participants liked the taste of China's plum, they still had lower WTP for China's plum than Taiwan plum. One may wonder whether the posting of second price have affected the bidding behavior. This hypothesis will be formally tested later. But if we just use the bidding results from the first trial, the average premium for Taiwan plum was calculated to be $\$ 22.03$ which is very close to the estimate of $\$ 22.38$ from the first three trials.

Table 2 presents the average bids by trial and country before and after tasting for oolong tea. Before tasting, the average bids are \$209, 113 and 111 for oolong teas from Taiwan, China and Vietnam, respectively. Taiwan tea’s premiums are $\$ 96$ and $\$ 98$ (or $85 \%$ and 88\%), respectively over China and Vietnam tea. After tasting, the average bids increased to \$237 and \$133 for Taiwan and China tea, respectively, but decreased slightly to $\$ 110$ for Vietnam 
tea. These results show that the bid premiums for Taiwan tea decreased to $\$ 90$ from $\$ 96$ over China tea, but increased to $\$ 113$ over Vietnam tea after tasting. These findings indicate that tasting did affect participants' WTP for various teas, but not as dramatic as the case for charcoal-smoked plums. In the experiment, we asked respondents what kind of tea they liked the best after tasting. The responses show that $72 \%$ of the participants liked Taiwan tea the best, 21\% liked China tea, 3\% liked Vietnam tea the best, 3\% saying no differences among the three, and 1\% giving no opinion. Therefore, tasting raised the bids for Taiwan and China teas, but lowering the bids for Vietnam tea.

Overall, these auction results clearly show stronger preferences by Taiwanese consumers for Taiwan oolong tea over those from China or Vietnam. This finding is further substantiated by the number of zero bids. For the first trial, $26.7 \%$ of participants bid zero for China plum and only $2.6 \%$ did the same for Taiwan plum. After tasting the percentage of zero bids for China plum decreased to $14 \%$ and for Taiwan plum the percentage increased to $5 \%$ after tasting. Still, the number of participants who did not want to pay anything for China plum was much higher than those for Taiwan plum. In the case of oolong tea, the percentages of zero bids in the first trial were $2.6 \%, 16 \%$, and $11 \%$ for Taiwan, China and Vietnam, respectively. After tasting, these percentages changed to $0.9 \%, 10 \%$ and $9 \%$, respectively for Taiwan, China and Vietnam teas. There were many more participants refusing to bid on China and Vietnam teas than Taiwan tea. Those bidding zero for Taiwan tea did so because they did not drink tea, and thus did not want to buy it.

After auctions, we had participants filling out a questionnaire collecting data on purchasing behavior, personal and demographic information. The descriptive statistics for all variables used in our econometric estimation will be detailed later. Here we will highlight some interesting results. Table 3 presents the responses on factors affecting the participant's food purchase. Results show that the most important factors affecting their food purchase are freshness and safety as more than 93\% of the respondents ranked them as "very important". 
Also more than $92 \%$ of the respondents ranked COOL as either somewhat or very important. Certification label is also highly ranked. Note that only $47 \%$ of the respondents ranked “price” as very important. Overall, Taiwanese consumers ranked safety and its related factors such COOL or certification more important than price. Table 4 shows that safety is either slightly or much more important than freshness if they are the only two factors being considered and compared.

Figure 1 shows the distribution of frequency on food label checking by the participants in three different cities. Results show majority of participants often or always check food labels. In Kaoshiung, 59\% of participants always checked food labels. In Taipei, 84\% of participants checked food labels either often or always. Figure 2 shows that Taiwanese consumers are not very happy with the government handing food safety as 55\% of participants were unsatisfied and 9.5\% were very unsatisfied with the government's handling of food safety matters.

We also asked about the country of origin for the imported food they ever purchased. The percentages of ever purchasing food items from Japan and the U.S. are $72 \%$ and $57 \%$, respectively. Interestingly only $25 \%$ and $18 \%$ of participants indicated that they have purchased food from China and Southeast Asia in the past. It is no wonder without COOL, the percentage of Taiwanese consumers knowing they ever purchased food from China is so low. Our survey also shows that $75 \%$ of respondents were willing to pay for the cost of COOL if its implementation would increase food price by 1-5\%.

\section{Econometric Analysis}

\section{Test of Affiliations}

In order to understand whether the posted second price would affect the bids in the successive trials, we investigate the possibility of the affiliation. It is possible that participants might adjust their bid after seeing the posted price which is the second highest bid. 
Specifically, they may increase their bids if the posted price is higher than their last bids. Otherwise, they may decrease the bids. However, if there is no affiliation, there is no correlation between the bid adjustment and the price difference between the posted price and previous bids. For testing affiliation, we specify the following regression model:

$$
\Delta B_{i, t}=\beta_{0}+\beta_{1} \Delta P_{i, t-1}+\beta_{2} t+\varepsilon_{i, t}
$$

where $\Delta B_{i, t}$ indicates the bid in trial t minus the bid in trial t-1 and $\Delta P_{i, t-1}$ denotes the posted price in trial $\mathrm{t}-1$ minus the participant $i$ 's bids in trial $\mathrm{t}-1$. Subscript $i$ and $t$ represent individual and trial. The trial variable $t$ is observed with $2, \ldots, 6$ because we had six trials in each experiment.

Table 5 shows that the posted price in trial $t-1$ has a significant and positive effect on participant's bid in trial t. That is, participants would increase their bids for both plum and tea if the previously posted price was higher than their previous bids. Since participants would adjust their bids during the repeated trials, the dummy variables for trials should be included in the bid regression equation auctions. According to Corrigan and Rousu (2006), in order to avoid the effect of affiliation, it is better to compute the price premium than the WTP for auctioned products. Therefore, we will conduct our econometric estimations for both WTP and premium in the next session.

\section{Estimation of Bid and Premium Functions}

We next attempt to investigate factors affecting the participant's bidding behavior. Since there are zero bids, the dependent variables have values of zero. Therefore, one appropriate model is Tobit model. We specify participants' bids are function of demographic variables, purchasing behavior and attitudes, information and risk perception and other experimental design variables such as trials and tasting. We will also estimate Taiwan product premium functions defined as the difference between bids for Taiwan product and those imported from 
China or Vietnam. Since the premium may be positive or negative, the ordinary least squares (OLS) is appropriate for this estimation.

Table 6 presents the definitions of all dependent and independent variables used in these two econometric models - bid and premium functions. Table 6 also shows the mean and standard deviation of each variable from the total sample of 116 participants. The descriptive statistics show that the mean bid of Taiwan charcoal plum from all six trials is $\$ 55$ dollars which is much higher than \$36 for China plum. The mean bids for Taiwan, China and Vietnam oolong teas are $\$ 223,123$, and 110 , respectively. The average age of the participants is 38.67 and males accounts for $51 \%$ of the sample. Note that the age distribution and sex were controlled by our experimental design. Family size of the participants is 3.84 while $52 \%$ of participants had household income in 2008 greater than $\$ 600,000$.

Mean statistics also show that $44 \%$ of participants mostly or always purchased food from traditional markets. Many Taiwanese consumers still prefer traditional markets due to their preference for freshness. These markets present huge challenge for enforcing the COOL regulations in Taiwan. Table 6 also shows that $80 \%$ of participants often or always checked food labels. Among the participants, $10 \%$ indicated that they received most information from packages. With respect to factors affecting participants' food purchasing, 94\% said price is somewhat or very important while $98 \%$ indicating freshness and safety are somewhat or very important. Results also show that $68 \%$ of participants were worried about the safety of imported foods and only $16 \%$ of them were satisfied with the government handling food safety matters.

After excluding the participants not filling out the survey questionnaire completely and carefully, the samples used for Tobit and OLS regressions include 113 participants for charcoal-smoked plums and 114 for oolong teas. Since there are six trials, we have sample sizes of 678 and 684 for plums and teas, respectively.

Table 7 shows the regression results on bids and bid premiums. For charcoal-smoked 
plum, the positive sign of BUYIM means that participants with experiences of buying imported food bid more for Taiwan plum. The reason might be that these participants think Taiwan produced plum are better than those imported. Negative signs for PRICE imply that a participant bid more for China plum if he/she thinks price is an important factor affecting their food purchase.

The variable GOVFS shows that respondents will bid more for Taiwan plum if they are satisfied with the government's handling on food safety matters. Moreover, females bid higher for Taiwan plum as the signs for SEX are negative. Because most of main food shoppers in Taiwanese households are females, they are more concerned about the issues of food safety and family health than male shoppers. FE has negative signs indicating that participants who spend more on food are less likely to bid more for Taiwan plum. Positive signs for TINC imply that wealthier people tend to bid higher for Taiwan plum.

Consider next the Tobit bid equation for China plum; variables PRFR, AGE and TASTE are significant. These variables are also significant in the OLS results of the bid premiums for Taiwan plum over China plum. These results show that the respondents who think price is more important than freshness are less likely to bid high for Taiwan plum. Elder people bid higher for China plum (AGE). Elder people should care about their health, but they may be more concerned about the attributes of the food products instead of the country of origin. On the other hand, young people care more about the country of origin, so they are willing to bid higher premium for Taiwan plum. We can also see such result in the premium equation for AGE.

One of our objectives is to examine the impact of product tasting on auction results. Positive sign for TASTE in the Tobit China plum equation implies that participants tend to bid higher for China plum after tasting. Moreover, tasting put negative effects on the bid difference between Taiwan and China plums.

The variables, BUYSP, INFOF, LACOST, MAR and ZONE3 all have the same sign in 
both bid equations. Positive signs for BUYSP imply that participants who have experience of buying charcoal-smoked plum are willingness to bid more on both plums. Positive signs for INFOF imply participants whose food information is mostly from the package tend to bid higher on plum. Positive signs for LACOST show that participants who are willing to pay $1 \%$ to $5 \%$ additional cost for implementing the country of origin labeling tend to bid more. Moreover, participants who are married bid higher as MAR has positive signs. Nevertheless, the positive effect on bids of China plum is more significant. Positive signs for ZONE3 imply that Kaohsiung participants tend to bid higher than those in other cities. Although ZONE3 is significant and positive on the bids for both Taiwan and China plum, the effect on the Taiwan plum is more in magnitude. Additionally, positive signs for MARKET, FRSA and RISK show that the participants who mostly or always purchase food in the traditional market, view freshness as a more important factor for buying food than safety and think contaminated imported food is the food safety issue they care about the most tend to bid more on both plums.

Besides, FRESH and PRSA are significant and have positive signs for the bid premiums for Taiwan plum over China plum. Participants who thinks freshness is an important factor of making decision on food buying bid more for Taiwan plum relative to China plum. Participants who view price as a more important factor than safety tend to bid higher for Taiwan plum.

Let us examine the Tobit and OLS results for oolong tea. Premium1 is the bid premium for Taiwan tea over China tea and Premium2 in the bid premium for Taiwan tea over Vietnam tea. The variables RISK, EDU1, EDU3, FAM10 and FE are all significant for the bids of Taiwan tea and the bid premiums of Taiwan tea over China tea. Participants who think contaminated imported food as the most important food safety issue (RISK) are willing to pay more for Taiwan tea relative to China tea. Both EDU1 and EDU3 have a positive sign, but EDU3 has more significant effect on bids. Such results are different from the results of 
plum and Loureiro and Umberger (2005). The reason might be that there have been so many negative reports about tea in recent years. Hence, higher educated participants become willing to pay more premiums for Taiwan tea, and the result is the same as Chang (2008). Positive signs for FAM10 imply that participants who have children aged less than ten years old tend to bid higher for Taiwan tea. Negative signs for FE are the same as the results for plum, suggesting that participants with higher food expenditure will bid less for Taiwan tea. Furthermore, EDU1, EDU3, FAM10, FE, TRAIL1 and TASTE are significant for bids of Taiwan tea and the bid premiums of Taiwan tea over Vietnam tea. The explanations for EDU1, EDU3, FAM10 and FE are similar to those provided previously regarding China tea. Negative signs for TRAIL1 show that bids and bid premiums are lower in the first trail.

As to the variable TASTE, the participants tend to bid higher after tasting for both Taiwan and China teas, but lower for Vietnam tea although it is not statistically significant. As a result, tasting did not affect bid premium over China tea, but significantly higher for the premium over Vietnam tea. These results are different from those found for plums. Therefore, tasting affects bidding behavior, but the results depend on products. It is important to add product tasting for food products such as preserved plums or tea.

There are some other variables which have significant effects on bids of oolong tea. The variable FRSA shows if respondents place more importance on freshness relative to safety, then they will bid less for Taiwan tea relative to China or Vietnam tea. INFOF has a significant and positive sign for three teas; that is, participants whose food information is from the package bid higher for three teas. Furthermore, respondent who have experience of buying tea (BUYTEA) tend to bid lower and those with experience of buying imported food (BUYIM) tend to bid higher. Also, respondents who view price more important than freshness (PRFR) bid more for China and Vietnam teas. Positive signs for TINC and ZONE3 imply that wealthier people bid more for every tea and the participants living in Kaohsiung tend to bid higher for all three teas. 
Regarding GOVFS, respondents who are more satisfied with the government's handling of food safety tend to bid higher for Taiwan tea. Older people (AGE) have less willingness to bid higher premiums for Taiwan tea as there are positive signs for the bids of China and Vietnam teas and negative sign for bid premium for Taiwan tea over China tea. Participants like China and Vietnam teas more if they consider price is a very important factor for making decision on food purchase (PRICE). Positive signs for MAR show that married people tend to bid more for tea.

Table 8 shows the marginal effects of the variables with estimated significant coefficients from Tobit regressions. For a continuous variable, the marginal effect can be computed from the Tobit regression results directly (See Wooldridge 2006). For a dummy variable, we can compute the difference between $E\left(y_{i} \mid y_{i}>0, x_{j}=1\right)$ and $E\left(y_{i} \mid y_{i}>0, x_{j}=0\right)$. For AGE, one additional year will raise the WTP by $\$ 0.15$ for Taiwan plum and \$0.81 for China plum. As to oolong tea, each additional year of age will raise the WTP by $\$ 0.93, \$ 2.44$ and $\$ 1.58$ for teas from Taiwan, China and Vietnam, respectively. The results for TASTE indicate that after tasting, the bids raise by $\$ 4.74$ for Taiwan plum, \$11.54 for China plum, \$28.22 for Taiwan tea, and \$20.39 for China tea, but lower by $\$ 1.96$ for Vietnam tea. The marginal effects for other dummy variables can be interpreted similarly.

We also run the same regressions using auction results before and after tasting, i.e., Trials 1-3 and Trials 4-6, respectively. We found that the regression results are very similar in terms of sign to those using the entire six trials reported in Table 7. Of course the coefficient magnitudes changed somewhat with some smaller while others larger. There are fewer numbers of significant variables in both regressions. Specifically in Table 7, the total number of significant variables excluding TASTE is 104 while there are only 94 and 85 significant variables in before tasting and after tasting regressions, respectively. In order to save space 
these regression results are not presented here.

As mentioned previously, in order to avoid the effect of affiliation, it is better to estimate the premium rather than the WTP. We compare the estimated bid equations and the premium function and find that there are more significant variables in the estimated premium functions than the individual bid equations. While there are 17 significant variables in the premium equation for plum, only 13 and 12 significant variables for the bid functions for Taiwan and China plum, respectively. For teas, the Premium 1 equation (Taiwan vs. China) has 16 significant variables which are more than 13 significant variables in the bid equations for all three teas as well as the Premium 2 equation for Taiwan vs. Vietnam. These results suggest that the regression performance for the premium equations is better than those bid functions.

Table 9 presents the estimated WTP by products and estimated premiums for Taiwan products over those from either China or Vietnam. We present the computation results for all trials using Tobit and OLS regressions in Table 7 and the regression results using data before and after tasting separately (but not reported in the paper). When computing the \% premium from the estimated premium, we used the average bid for the base product (such as China plum) reported in Tables 1 and 2. For example, for the case of before tasting, the estimated premium for Taiwan plum is $\$ 24.84$. Using the average bid of 29.78 for Trials 1-3 in Table 1 , we computed the $\%$ premium for Taiwan plum to be $83 \%$. Table 9 shows there are substantial premiums for Taiwan charcoal-smoked plum and Taiwan tea. The estimated premiums for Taiwan oolong tea ranges from $83 \%$ - 109\% while the estimated premiums for Taiwan charcoal-smoked plum ranges from 55\% to 66\%. These are very high premiums for Taiwan products. The results also suggest that tasting affect auction bids. The estimated premiums decreased after tasting for Taiwan plum and Taiwan tea over China tea, but increased for Taiwan tea over Vietnam tea. We also note that the estimated \% premiums from the premium equations are higher than those estimated from the individual bid functions. 


\section{Policy Implications}

After accession to the World Trade Organization (WTO), Taiwan's agriculture sector has faced stiff foreign competition. Recently the Taiwan government has attempted to negotiate with China to sign an Economic Cooperation Framework Agreement (ECFA). Even though the government has claimed that this will not lift the ban on the imports of 830 agricultural products from China. However, many banned agricultural products from China have entered into Taiwan market through smuggling or importing via a third country. Oolong tea is the case in point, China tea has been imported into Taiwan through Vietnam as Vietnam tea. Without COOL, these smuggled and imported products have been sold pretending they are domestically produced. In order to reduce the impacts of WTO accession and ECFA, it is extremely important to enforce a rigorous traceability system and COOL regulation.

This study has demonstrated that Taiwanese consumers have a strong preference for foods produced domestically. They prefer Taiwan products not because of their patriotism, but because of their concerns about food safety. Taiwanese demand for food safety is very high especially after the China milk power (melamine) event in September 2008. With high premiums for Taiwan food products estimated in this study, many imported food products such as preserved fruits and tea from China, Vietnam and other Southeast Asian countries if clearly labeled with COOL will face strong competition with those produced domestically. Almost certainly these imported or smuggled products have to reduce their price substantially to find buyers. In many cases, Taiwanese consumers simply would not buy products from China. Both Taiwanese consumers and food producers will gain substantially with rigorously enforced COOL regulations in Taiwan.

Taiwan does have COOL regulations for both packaged food in 2008 and bulk imported food and agricultural products beginning 2010. Unfortunately, these laws have not been forcefully implemented. Food merchants have been earning unlawful profits by not telling consumers about the true country of origin of their imported products or by mixing the 
imported products with domestically produced ones. According to the present government COOL regulation, if China oolong tea is mixed with $1 \%$ of Taiwan oolong tea, they can be sold as Taiwan tea. This type of government regulation is simply unreasonable and it should be changed to protect both consumers and domestic producers.

\section{Concluding Remarks}

The purpose of this study is to evaluate the economic benefits of COOL regulation by estimating the consumer's WTP for Taiwan product vs. other imported products if clearly labeled with their countries of origin. We employed the Vickrey second-price sealed-bid auction and conducted auctions in three major cities in Taiwan in 2009. In each experimental session, we conducted three repeated trials before product tasting and another three trials after tasting. We used charcoal-smoked plums from Taiwan and China and oolong teas from Taiwan, China, and Vietnam as auctioned products. These products represent two categories of food and agricultural products (preserved fruits and tea) for which the problems of deception are most severe. We recruited 116 food shoppers to participate in these auction experiments. In addition to auctions, we also collected information on participants' food safety concerns, food purchase behavior, risk perception and demographic characteristics. Survey results indicate that auction participants were very concerned about food safety and COOL.

In order to investigate factors affecting bidding behavior, we estimated Tobit bid models for each product and the OLS premium functions. The regression results show that many demographic variables, risk perception and experimental design features were significant factors affecting participants' bids and thus premiums for Taiwan products. In particular, product tasting was found to affect the participants' WTP positively or negatively depending on products. Specifically, tasting raised bids for Taiwan and China teas, but lowered bids for Vietnam tea. Tasting also raised bids for both Taiwan and China plums, though with different 
magnitudes. Auction results with tasting are more credible because they reflect the real market situation. It is also found that the estimated OLS premium equations have more significant variables than the individual Tobit bid functions.

The econometric results show very high premiums for Taiwan products, ranging from $83 \%$ to $109 \%$ for tea and $55 \%$ to $66 \%$ for charcoal-smoked plum. These high premiums were caused by food safety concerns, not simply usual quality attributes like those studied by Carter, et al. (2006). Note that production areas for preserved fruits and tea have been greatly reduced over the last two decades due to the competition from low-price imports. With COOL, these high price premiums will undoubtedly increase the domestic supply of preserved fruits and tea. However, Taiwanese consumers have such strong preferences for food and agricultural products produced domestically. Positive premiums for Taiwan products should be sustained in the long run. These findings clearly show that if all foods and agricultural products are clearly labeled with their countries of origin, Taiwanese consumers and food producers stand to benefit greatly with COOL. The CCOL can promote Taiwan as a brand name, Thus it is a great marketing tool as well. The COOL would be one of the best instruments to reduce the negative impacts of agricultural trade liberalization under WTO or ECFA. 


\section{References}

Brester, G. W., J. M. Marsh and J. A. Atwood. 2004. "Distributional Impacts of Country-of-Origin Labeling in the U. S. Meat Industry.” Journal of Agricultural and Resource Economics 29: 206-227.

Chang, Chung-Yu. 2008. "Willingness to Pay Premium for Foods Produced in Taiwan and Its Implications for Country of Origin Labeling,” Master Thesis, Department of Economics, National Chung Cheng University, Taiwan.

Colin Carter, B. Krissoff and A.P. Zwane .2006. “Can Country of Origin Labeling Succeed as a Marketing Tool for Produce? Lessons from Three Case Studies.” Canadian Journal of Agricultural Economics 54: 513-530.

Coppinger, V., V. Smith, and J. Titus. "Incentives and Behavior in English, Dutch and Sealed-Bid Auctions.” Economic Inquiry 18 (1980): 1-22.

Corrigan, Jay R. and Matthew C. Rousu.2006. "Posted Prices and Bid affiliation: Evidence from Experimental Auctions.” American Journal of Agricultural Economics 88 (4): 1078-1090

Haab, T. C., and K. E. McConnell. 2002. Valuing Environmental and Natural Resources: The Econometrics of Non-Market Valuation. Cheltenham, U.K. and Northampton, MA, U.S.A.: Edward Elgar.

Hayes, D. J. and S. R. Meyer. 2003. Impact of Country of Origin Labeling on U.S. Pork Exports. Report prepared for the National Pork Production Council. Available at http://www.nppc.org/news/stories/2003/COOLReport.pdf.

Hoffman, Elizabeth, Dale, J.M, Dipankar Chakravart, Ray A. Field and Gle D. Whilpple. 1993. "Using Laboratory Experimental Auction in Marketing Research: A Case Study of New Packaging for Fresh Beef.” Marketing Science 12 (3): 318-338.

Huffman, W. E., J. F. Shogren, M. Rousou, and A. Tegene. 2003. "Consumer Willingness to Pay for Genetically Modified Food Labels in a Market with Diverse Information: Evidence from Experimental Auctions.” Journal of Agricultural and Resource Economics 28, 481-502.

List, John A. and Jason F. Shogren. 1999. "Price Information and Bidding Behavior in 
Repeated Second-Price Auctions.” American Journal of Agricultural Economics 81: 942-949.

Loureiro, M. L. and W. J. Umberger. 2003. "Estimating Consumer Willingness to Pay for Country-of-Origin Labeling." Journal of Agricultural and Resource Economics 28: 287-301.

Lusk, J. L. and J. D. Anderson. 2004. "Effects of Country-of-Origin Labeling on Meat Producers and Consumers." Journal of Agricultural and Resource Economics 29: 185-205.

Lusk, Jayson L. and Jason F. Shogren. 2007. Experimental Auctions: Methods and Applications in Economic and Marketing Research. New York: Cambridge University Press.

Ministry of Interior, Taiwan.2009. Age Distribution of Population in Taiwan 2008, Annual Report of Department of Interior. Statistical Information Website http://www.moi.gov.tw/stat/ Accessed December 31, 2009.

Mitchell, R. and R. Carson. 1989. Using Surveys to Value Public Goods: The Contingent Valuation Method. Washington, D.C.: Resources for the Future.

Rude, J., J. Iqbal, and D. Brewin. 2006. “The Little Piggy Went to Market with a Passport: The Impacts of U.S. Country of Origin Labeling on the Canadian Pork Sector.” Canadian Journal of Agricultural Economics 54: 401-420.

Schupp, A. and J. Gillespie. 2001. "Handler Reaction to Potential Compulsory Country-of-Origin Labeling of Fresh or Frozen Beef." Journal of Agricultural and Applied Economics 33:161-171.

Shogren, J., J. List, and D. Hayes.2000. "Preference Learning in Consecutive Experimental Auctions.” American Journal of Agricultural Economics 82: 1016-1021.

Shogren, J., M. Margolis, C. Koo, and J. List.2001. “A Random nth-Price Auction.” Journal of Economic Behavior and Organization 46: 409-421.

Umberger, W. J. and D. M. Feuz. 2004. "The Usefulness of Experimental Auctions in Determining Consumers' Willingness to Pay for Quality Differentiated Products.” Review of Agricultural Economics 26:1-16. 
Umberger, W. J., D. M. Feuz, C. R. Calkins, and B. M. Sitz. 2003. “Country-of-Origin Labeling of Beef Products: U. S. Consumers’ Perceptions.” Journal of Food Distribution Research 34: 103-116.

VanSickle, J., R. McEowen, C. R. Taylor, N. Harl, and J. Connor. 2003. “Country of Origin Labeling: A Legal and Economic Analysis.” Paper No. PBTC 03-5, International Agricultural Trade and Policy Center, University of Florida, Gainesville, Florida. http://www.iatpc.fred.ifas.ufl.edu//docs/policy-brief/PBTC-03_5.pdf

Vickrey, W. 1961. "Counter Speculation, Auctions, and Competitive Sealed Tenders." Journal of Finance 16:8-37.

Wooldridge, J.M. 2006. Introductory Econometrics, a Modern Approach, 3rd edition. Mason, Ohio: Thomson Southwestern. 
Table 1. Average Bids for Charcoal-Smoked Plum (Unit: New Taiwan Dollars per 150 Grams)

\begin{tabular}{ccccc}
\hline \multirow{2}{*}{ Trial } & \multicolumn{2}{c}{ Taiwan } & \multicolumn{2}{c}{ China } \\
\cline { 2 - 3 } \cline { 5 - 6 } & Mean & $($ MAX, MIN $)$ & Mean & (MAX, MIN) \\
\hline Trial 1 & 48.50 & $(230,0)$ & 26.47 & $(180,0)$ \\
Trial 2 & 52.23 & $(170,0)$ & 29.54 & $(150,0)$ \\
Trial 3 & 55.75 & $(170,0)$ & 33.32 & $(150,0)$ \\
Trials 1 3 & 52.16 & $(230,0)$ & 29.78 & $(180,0)$ \\
& \multicolumn{5}{c}{ After Tasting } \\
Trial 4 & 55.06 & $(180,0)$ & 39.51 & $(150,0)$ \\
Trial 5 & 57.28 & $(180,0)$ & 41.32 & $(200,0)$ \\
Trial 6 & 58.35 & $(180,0)$ & 43.12 & $(250,0)$ \\
Trials 4 6 & 58.90 & $(180,0)$ & 41.32 & $(250,0)$ \\
Trials 1 6 & 54.53 & $(230,0)$ & 35.55 & $(250,0)$ \\
\hline N & \multicolumn{5}{c}{696} \\
\hline
\end{tabular}

Table 2. Average Bids for Oolong Tea (Unit: New Taiwan Dollars per 150 Grams)

\begin{tabular}{|c|c|c|c|c|c|c|}
\hline \multirow{2}{*}{ Trail } & \multicolumn{2}{|r|}{ Taiwan } & \multicolumn{2}{|r|}{ China } & \multicolumn{2}{|c|}{ Vietnam } \\
\hline & Mean & (MAX, MIN) & Mean & (MAX, MIN) & Mean & (MAX, MIN) \\
\hline Trail 1 & 185.77 & $(800,0)$ & 102.42 & $(400,0)$ & 103.59 & $(400,0)$ \\
\hline Trail 2 & 216.25 & $(650,0)$ & 116.99 & $(370,0)$ & 114.92 & $(310,0)$ \\
\hline Trail 3 & 224.45 & $(530,5)$ & 118.66 & $(380,0)$ & 115.88 & $(350,0)$ \\
\hline Trails 1 3 & 208.82 & $(800,0)$ & 112.69 & $(400,0)$ & 111.47 & $(400,0)$ \\
\hline \multicolumn{7}{|c|}{ After Tasting } \\
\hline Trail 4 & 229.28 & $(550,0)$ & 130.19 & $(425,0)$ & 108.19 & $(360,0)$ \\
\hline Trail 5 & 239.33 & $(550,0)$ & 133.09 & $(390,0)$ & 110.31 & $(320,0)$ \\
\hline Trail 6 & 242.53 & $(530,0)$ & 135.96 & $(365,0)$ & 110.01 & $(305,0)$ \\
\hline Trails 4 6 & 237.05 & $(550,0)$ & 133.08 & $(425,0)$ & 109.50 & $(360,0)$ \\
\hline Trails 1 6 & 222.93 & $(800,0)$ & 122.88 & $(425,0)$ & 110.48 & $(400,0)$ \\
\hline $\mathrm{N}$ & \multicolumn{6}{|c|}{696} \\
\hline
\end{tabular}


Table 3. Ranking of Factors Affecting Food Purchasing

\begin{tabular}{|c|c|c|c|c|c|}
\hline Factors & $\begin{array}{c}\text { Very } \\
\text { Unimportant }\end{array}$ & $\begin{array}{l}\text { Somewhat } \\
\text { Unimportant }\end{array}$ & Neutrality & $\begin{array}{l}\text { Somewhat } \\
\text { Important }\end{array}$ & $\begin{array}{c}\text { Very } \\
\text { Important }\end{array}$ \\
\hline Price & $0.00 \%$ & $2.59 \%$ & $3.45 \%$ & $47.41 \%$ & $46.55 \%$ \\
\hline Brand & $0.86 \%$ & $6.90 \%$ & $7.76 \%$ & $49.14 \%$ & $35.34 \%$ \\
\hline Freshness & $1.72 \%$ & $0.00 \%$ & $0.00 \%$ & $5.17 \%$ & $93.10 \%$ \\
\hline Safety & $1.72 \%$ & $0.00 \%$ & $0.00 \%$ & $1.72 \%$ & $96.55 \%$ \\
\hline COOL & $1.72 \%$ & $1.72 \%$ & $3.45 \%$ & $40.52 \%$ & $52.59 \%$ \\
\hline Nutrition & $2.59 \%$ & $2.59 \%$ & $12.07 \%$ & $34.48 \%$ & $48.28 \%$ \\
\hline $\begin{array}{c}\text { Convenience in } \\
\text { Using }\end{array}$ & $1.72 \%$ & $6.03 \%$ & $11.21 \%$ & $45.69 \%$ & $35.34 \%$ \\
\hline $\begin{array}{c}\text { Convenience in } \\
\text { Buying }\end{array}$ & $4.31 \%$ & $4.31 \%$ & $12.07 \%$ & $42.24 \%$ & $37.07 \%$ \\
\hline $\begin{array}{c}\text { Certification } \\
\text { Labels }\end{array}$ & $1.72 \%$ & $1.72 \%$ & $5.17 \%$ & $23.28 \%$ & $68.10 \%$ \\
\hline
\end{tabular}

Table 4. Tradeoff between Freshness and Safety

\begin{tabular}{ccc}
\hline Item & Number & Percentage \\
\hline Freshness is much more important than safety & 13 & $11.21 \%$ \\
Freshness is slightly more important than safety & 8 & $6.90 \%$ \\
Safety is slightly more important than freshness & 44 & $37.93 \%$ \\
Safety is much more important than Freshness & 51 & $43.97 \%$ \\
\hline $\mathrm{N}$ & \multicolumn{2}{c}{116} \\
\hline
\end{tabular}

Table 5. Affiliation Test Results (OLS)

\begin{tabular}{ccccccc}
\hline \multirow{2}{*}{ Variable } & \multicolumn{2}{c}{ Charcoal-Smoked Plum } & & \multicolumn{3}{c}{ Oolong Tea } \\
\cline { 2 - 4 } \cline { 5 - 7 } & Taiwan & China & & Taiwan & China & Vietnam \\
\hline \multirow{2}{*}{ Constant } & $-16.05^{* * *}$ & $-5.86^{*}$ & & -8.7 & $-11.25^{*}$ & $-19.24^{* * *}$ \\
& $(3.51)$ & $(3.02)$ & & $(8.17)$ & $(6.44)$ & $(5.59)$ \\
$\mathrm{P}$ & $0.13^{* * *}$ & $0.08^{* * *}$ & & $0.11^{* * *}$ & $0.11^{* * *}$ & $0.14^{* * *}$ \\
& $(0.02)$ & $(0.02)$ & & $(0.02)$ & $(0.02)$ & $(0.02)$ \\
$\mathrm{t}$ & 0.67 & 0.05 & & $-3.22^{* *}$ & $-2.17^{* *}$ & $-1.78^{*}$ \\
& $(0.51)$ & $(0.43)$ & $(1.36)$ & $(1.09)$ & $(0.96)$ \\
\hline & 565 & 565 & 570 & 570 & 570
\end{tabular}

Notes: $\mathrm{N}$ represents the number of observations. The symbols***,** and * denote that the variables are significant at a $1 \%, 5 \%$ and $10 \%$ level, respectively. Numbers in parentheses are estimated standard errors. 
Table 6. Variable Definition and Coding

\begin{tabular}{|c|c|c|c|}
\hline Variable & Definition and Coding & Mean & S.D. \\
\hline \multicolumn{4}{|c|}{ Dependent Variables } \\
\hline SPt & Bids of charcoal-smoked plum produced in Taiwan (NT\$) & 54.53 & 36.52 \\
\hline SPc & Bids of charcoal-smoked plum imported from China (NT\$). & 35.55 & 32.93 \\
\hline OTt & Bids of oolong tea produced in Taiwan (NT\$). & 222.93 & 120.86 \\
\hline OTc & Bids of oolong tea imported from China (NT\$). & 122.88 & 84.71 \\
\hline OTv & Bids of oolong tea imported from Vietnam (NT\$). & 110.48 & 74.38 \\
\hline \multicolumn{4}{|c|}{$\underline{\text { Trial Variables }}$} \\
\hline TRIAL 1 & 1 if first trial; 0 otherwise. & 0.17 & 0.37 \\
\hline TRIAL 2 & 1 if second trial; 0 otherwise. & 0.17 & 0.37 \\
\hline TRIAL 3 & 1 if third trial; 0 otherwise. & 0.17 & 0.37 \\
\hline TRIAL 4 & 1 if fourth trial; 0 otherwise. & 0.17 & 0.37 \\
\hline TRIAL 5 & 1 if fifth trial; 0 otherwise. & 0.17 & 0.37 \\
\hline TRIAL 6 & 1 if sixth trial; 0 otherwise. & 0.17 & 0.37 \\
\hline TASTE & 1 if auction was done after tasting; 0 otherwise. & 0.50 & 0.50 \\
\hline \multicolumn{4}{|c|}{$\underline{\text { Demographic Variables }}$} \\
\hline AGE & Age of respondents as of 2009. & 38.67 & 11.06 \\
\hline SEX & 1 if male, 0 if female. & 0.51 & 0.50 \\
\hline MAR & 1 if married; 0 otherwise. & 0.46 & 0.50 \\
\hline EDU1 & 1 if primary or secondary school; 0 otherwise. & 0.23 & 0.42 \\
\hline EDU2 & 1 if high school; 0 otherwise. & 0.34 & 0.48 \\
\hline EDU3 & 1 if college, university or above; 0 otherwise. & 0.43 & 0.50 \\
\hline FAMSIZE & Number of household members. & 3.84 & 1.19 \\
\hline FAM10 & 1 if household has children under age 10; 0 otherwise. & 0.32 & 0.47 \\
\hline $\mathrm{FE}$ & $\begin{array}{l}1 \text { if household food expenditure per week }>3,000 \text {; } \\
0 \text { otherwise. }\end{array}$ & 0.28 & 0.45 \\
\hline INC & 1 if personal income per month $>\$ 50,000 ; 0$ otherwise. & 0.10 & 0.31 \\
\hline TINC & 1 if household income in $2008>\$ 600,000 ; 0$ otherwise. & 0.52 & 0.50 \\
\hline BMI & 1 if $\mathrm{BMI}<24$; 0 otherwise. & 0.61 & 0.49 \\
\hline ZONE1 & 1 if respondent is living in Taipei; 0 otherwise. & 0.33 & 0.47 \\
\hline ZONE2 & 1 if respondent is living in Taichung; 0 otherwise. & 0.32 & 0.47 \\
\hline ZONE3 & 1 if respondent is living in Kaohsiung; 0 otherwise. & 0.34 & 0.48 \\
\hline \multicolumn{4}{|c|}{ Purchasing Behavior and Attitude } \\
\hline MARKET & 1 if mostly or always purchasing in the traditional market; 0 otherwise. & 0.44 & 0.5000 \\
\hline CHECK & 1 if often or always check the food labeling; 0 otherwise. & 0.80 & 0.40 \\
\hline BUYIM & 1 if ever buy imported food; 0 otherwise. & 0.94 & 0.24 \\
\hline
\end{tabular}


Table 6. (Continued)

\begin{tabular}{|c|c|c|c|}
\hline BUYSP & 1 if ever buy charcoal-smoked plum; 0 otherwise. & 0.90 & 0.30 \\
\hline BUYTEA & 1 if ever buy oolong tea; 0 otherwise. & 0.85 & 0.36 \\
\hline \multicolumn{4}{|c|}{ Information and Perception } \\
\hline INFOF & 1 if food information is from package; 0 otherwise. & 0.10 & 0.31 \\
\hline INFOC & 1 if very well or somewhat informed about COOL; 0 otherwise. & 0.67 & 0.47 \\
\hline PRICE & 1 if price is somewhat or very important; 0 otherwise. & 0.94 & 0.24 \\
\hline BRAND & 1 if brand is somewhat or very important; 0 otherwise. & 0.84 & 0.36 \\
\hline FRESH & 1 if freshness is somewhat or very important; 0 otherwise. & 0.98 & 0.13 \\
\hline SAFETY & 1 if safety is somewhat or very important; 0 otherwise. & 0.98 & 0.13 \\
\hline COOL & 1 if COOL is somewhat or very important; 0 otherwise. & 0.93 & 0.26 \\
\hline NUTRI & 1 if nutrition is somewhat or very important; 0 otherwise. & 0.83 & 0.38 \\
\hline USECCON & 1 if convenience for using is somewhat or very important; 0 otherwise. & 0.81 & 0.40 \\
\hline BUYCON & 1 if convenience for buying is somewhat or very important; 0 otherwise. & 0.79 & 0.41 \\
\hline CAS & $\begin{array}{l}1 \text { if certification label (like CAS) is somewhat or very important; } \\
0 \text { otherwise. }\end{array}$ & 0.91 & 0.28 \\
\hline PRFR & 1 if price is slightly or much more important than freshness; 0 otherwise. & 0.12 & 0.33 \\
\hline PRSA & 1 if price is slightly or much more important than safety; 0 otherwise. & 0.04 & 0.20 \\
\hline PRCO & 1 if price is slightly or much more important than COOL; 0 otherwise. & 0.32 & 0.47 \\
\hline FRSA & $\begin{array}{l}1 \text { if freshness is slightly or much more important than safety; } \\
0 \text { otherwise. }\end{array}$ & 0.18 & 0.39 \\
\hline PRCAS & 1 if price is slightly or much more important than CAS; 0 otherwise. & 0.27 & 0.45 \\
\hline LACOST & $\begin{array}{l}1 \text { if respondent is willing to pay } 1 \% \sim 5 \% \text { premiums for COOL; } \\
0 \text { otherwise. }\end{array}$ & 0.75 & 0.44 \\
\hline RISK & $\begin{array}{l}1 \text { if respondent worries about safety of imported food; } \\
0 \text { otherwise. }\end{array}$ & 0.68 & 0.47 \\
\hline GOVFS & $\begin{array}{l}1 \text { if respondent is satisfied with government handling on food safety; } \\
0 \text { otherwise. }\end{array}$ & 0.16 & 0.36 \\
\hline TRACE & 1 if respondent believes in the traceability of label; 0 otherwise. & 0.86 & 0.35 \\
\hline
\end{tabular}


Table 7. Regression Results on Bids and Premiums

\begin{tabular}{|c|c|c|c|c|c|c|c|c|}
\hline \multirow[b]{2}{*}{ Variable } & \multicolumn{3}{|c|}{ Charcoal-Smoked Plum } & \multicolumn{5}{|c|}{ Oolong Tea } \\
\hline & $\begin{array}{l}\text { Taiwan } \\
\text { (Tobit) }\end{array}$ & $\begin{array}{l}\text { China } \\
\text { (Tobit) }\end{array}$ & $\begin{array}{l}\text { Premium } \\
\text { (OLS) }\end{array}$ & $\begin{array}{l}\text { Taiwan } \\
\text { (Tobit) }\end{array}$ & $\begin{array}{l}\text { China } \\
\text { (Tobit) }\end{array}$ & $\begin{array}{c}\text { Vietnam } \\
\text { (Tobit) }\end{array}$ & $\begin{array}{l}\text { Premium1 } \\
\text { (OLS) }\end{array}$ & $\begin{array}{c}\text { Premium2 } \\
\text { (OLS) }\end{array}$ \\
\hline Constant & $\begin{array}{l}-18.78 \\
(14.76)\end{array}$ & $\begin{array}{c}-69.48 * * * \\
(15.22)\end{array}$ & $\begin{array}{c}22.12 * * \\
(10.76)\end{array}$ & $\begin{array}{l}-24.14 \\
(42.77)\end{array}$ & $\begin{array}{c}-131.07 * * * \\
(34.78)\end{array}$ & $\begin{array}{l}-13.89 \\
(29.71)\end{array}$ & $\begin{array}{c}89.35 * * \\
(38.29)\end{array}$ & $\begin{array}{c}-1.82 \\
(32.47)\end{array}$ \\
\hline BUYSP & $\begin{array}{c}22.40^{* * * *} \\
(4.85)\end{array}$ & $\begin{array}{c}30.61^{* * *} \\
(5.08)\end{array}$ & $\begin{array}{l}-3.89 \\
(3.51)\end{array}$ & - & - & - & - & - \\
\hline BUYTEA & - & - & - & $\begin{array}{c}13.20 \\
(12.02)\end{array}$ & $\begin{array}{c}-32.90 * * * \\
(9.73)\end{array}$ & $\begin{array}{c}-24.34 * * * \\
(8.35)\end{array}$ & $\begin{array}{c}44.31^{* * *} \\
(10.83)\end{array}$ & $\begin{array}{c}35.31^{* * *} \\
(9.19)\end{array}$ \\
\hline MARKET & $\begin{array}{l}-4.70 \\
(3.03)\end{array}$ & $\begin{array}{c}-11.06 * * * \\
(3.09)\end{array}$ & $\begin{array}{l}3.89 * \\
(2.21)\end{array}$ & $\begin{array}{c}1.40 \\
(9.16)\end{array}$ & $\begin{array}{c}0.51 \\
(7.39)\end{array}$ & $\begin{array}{l}-6.41 \\
(6.38)\end{array}$ & $\begin{array}{l}-1.36 \\
(8.27)\end{array}$ & $\begin{array}{c}3.46 \\
(7.01)\end{array}$ \\
\hline INFOF & $\begin{array}{c}28.07 * * * \\
(5.06)\end{array}$ & $\begin{array}{c}31.25^{* * *} \\
(5.10)\end{array}$ & $\begin{array}{c}1.57 \\
(3.70)\end{array}$ & $\begin{array}{c}45.89 * * * \\
(15.42)\end{array}$ & $\begin{array}{c}70.67 * * * \\
(12.43)\end{array}$ & $\begin{array}{c}51.52 * * * \\
(10.71)\end{array}$ & $\begin{array}{l}-16.89 \\
(13.88)\end{array}$ & $\begin{array}{c}-5.37 \\
(11.78)\end{array}$ \\
\hline CHECK & $\begin{array}{l}-1.08 \\
(3.77)\end{array}$ & $\begin{array}{l}-6.21 \\
(3.85)\end{array}$ & $\begin{array}{c}3.23 \\
(2.75)\end{array}$ & $\begin{array}{c}7.10 \\
(11.40)\end{array}$ & $\begin{array}{l}-4.51 \\
(9.22)\end{array}$ & $\begin{array}{c}0.92 \\
(7.93)\end{array}$ & $\begin{array}{c}10.82 \\
(10.24)\end{array}$ & $\begin{array}{c}4.41 \\
(8.68)\end{array}$ \\
\hline BUYIM & $\begin{array}{l}11.71^{*} \\
(6.73)\end{array}$ & $\begin{array}{l}-8.21 \\
(6.82)\end{array}$ & $\begin{array}{c}20.45^{* * *} \\
(4.86)\end{array}$ & $\begin{array}{c}121.18 * * * \\
(20.10)\end{array}$ & $\begin{array}{c}68.97 * * * \\
(16.13)\end{array}$ & $\begin{array}{l}26.40^{*} \\
(13.82)\end{array}$ & $\begin{array}{c}50.52^{* * *} \\
(17.83)\end{array}$ & $\begin{array}{c}85.73 * * * \\
(15.12)\end{array}$ \\
\hline PRICE & $\begin{array}{c}-10.91 * * * \\
(3.08)\end{array}$ & $\begin{array}{c}1.05 \\
(3.13)\end{array}$ & $\begin{array}{c}-10.23 * * * \\
(2.25)\end{array}$ & $\begin{array}{c}-24.20 * * * \\
(9.12)\end{array}$ & $\begin{array}{l}14.23 * \\
(7.36)\end{array}$ & $\begin{array}{c}12.81 * * \\
(6.35)\end{array}$ & $\begin{array}{c}-33.84 * * * \\
(8.24)\end{array}$ & $\begin{array}{c}-33.90 * * * \\
(6.99)\end{array}$ \\
\hline FRESH & $\begin{array}{c}8.00 \\
(5.94)\end{array}$ & $\begin{array}{l}-4.78 \\
(6.01)\end{array}$ & $\begin{array}{c}12.49 * * * \\
(4.35)\end{array}$ & $\begin{array}{c}-65.66 * * * \\
(17.97)\end{array}$ & $\begin{array}{l}-11.86 \\
(14.42)\end{array}$ & $\begin{array}{c}-45.56 * * * \\
(12.47)\end{array}$ & $\begin{array}{c}-57.72 * * * \\
(16.23)\end{array}$ & $\begin{array}{l}-22.51 \\
(13.76)\end{array}$ \\
\hline PRFR & $\begin{array}{l}-2.42 \\
(3.38)\end{array}$ & $\begin{array}{c}8.22 * * \\
(3.47)\end{array}$ & $\begin{array}{c}-7.26 * * * \\
(2.48)\end{array}$ & $\begin{array}{c}-2.25 \\
(10.24)\end{array}$ & $\begin{array}{c}39.54^{* * *} \\
(8.27)\end{array}$ & $\begin{array}{c}26.74 * * * \\
(7.12)\end{array}$ & $\begin{array}{c}-35.24 * * * \\
(9.24)\end{array}$ & $\begin{array}{c}-26.46^{* * *} \\
(7.84)\end{array}$ \\
\hline PRSA & $\begin{array}{c}5.17 \\
(3.81)\end{array}$ & $\begin{array}{c}1.41 \\
(3.88)\end{array}$ & $\begin{array}{l}5.57 * * \\
(2.78)\end{array}$ & $\begin{array}{l}-17.18 \\
(11.56)\end{array}$ & $\begin{array}{l}-13.00 \\
(9.34)\end{array}$ & $\begin{array}{c}-30.80 * * * \\
(8.07)\end{array}$ & $\begin{array}{c}-3.93 \\
(10.42)\end{array}$ & $\begin{array}{l}10.12 \\
(8.84)\end{array}$ \\
\hline PRCO & $\begin{array}{c}9.52 * * * \\
(3.65)\end{array}$ & $\begin{array}{c}4.33 \\
(3.75)\end{array}$ & $\begin{array}{l}4.50 * \\
(2.67)\end{array}$ & $\begin{array}{c}-2.94 \\
(10.99)\end{array}$ & $\begin{array}{c}3.27 \\
(8.86)\end{array}$ & $\begin{array}{l}-1.63 \\
(7.63)\end{array}$ & $\begin{array}{l}-7.40 \\
(9.93)\end{array}$ & $\begin{array}{l}-1.89 \\
(8.42)\end{array}$ \\
\hline FRSA & $\begin{array}{c}1.02 \\
(2.96)\end{array}$ & $\begin{array}{c}15.42 * * * \\
(3.04)\end{array}$ & $\begin{array}{c}-10.39 * * * \\
(2.16)\end{array}$ & $\begin{array}{c}2.01 \\
(8.78)\end{array}$ & $\begin{array}{c}28.82 * * * \\
(7.12)\end{array}$ & $\begin{array}{c}22.54 * * * \\
(6.13)\end{array}$ & $\begin{array}{c}-20.63 * * * \\
(7.92)\end{array}$ & $\begin{array}{c}-18.36 * * * \\
(6.72)\end{array}$ \\
\hline LACOST & $\begin{array}{c}11.38 * * * \\
(3.37)\end{array}$ & $\begin{array}{c}16.04 * * * \\
(3.45)\end{array}$ & $\begin{array}{l}-3.25 \\
(2.46)\end{array}$ & $\begin{array}{c}15.48 \\
(10.15)\end{array}$ & $\begin{array}{l}12.13 \\
(8.19)\end{array}$ & $\begin{array}{c}7.59 \\
(7.05)\end{array}$ & $\begin{array}{c}3.14 \\
(9.17)\end{array}$ & $\begin{array}{c}6.97 \\
(7.78)\end{array}$ \\
\hline RISK & $\begin{array}{l}-0.16 \\
(3.57)\end{array}$ & $\begin{array}{c}-11.34 * * * \\
(3.67)\end{array}$ & $\begin{array}{c}7.74 * * * \\
(2.61)\end{array}$ & $\begin{array}{c}44.18^{* * *} \\
(10.81)\end{array}$ & $\begin{array}{l}-12.29 \\
(8.70)\end{array}$ & $\begin{array}{c}35.20^{* * *} \\
(7.52)\end{array}$ & $\begin{array}{c}53.73 * * * \\
(9.76)\end{array}$ & $\begin{array}{l}11.81 \\
(8.28)\end{array}$ \\
\hline GOVFS & $\begin{array}{l}8.02 * \\
(4.15)\end{array}$ & $\begin{array}{c}4.27 \\
(4.23)\end{array}$ & $\begin{array}{l}5.48 * \\
(3.03)\end{array}$ & $\begin{array}{c}18.95 \\
(12.59)\end{array}$ & $\begin{array}{c}2.19 \\
(10.16)\end{array}$ & $\begin{array}{c}1.85 \\
(8.73)\end{array}$ & $\begin{array}{l}21.70^{*} \\
(11.37)\end{array}$ & $\begin{array}{c}19.80 * * \\
(9.64)\end{array}$ \\
\hline
\end{tabular}


Table7. (Continued)

\begin{tabular}{|c|c|c|c|c|c|c|c|c|}
\hline \multirow[b]{2}{*}{ Variable } & \multicolumn{3}{|c|}{ Charcoal-Smoked Plum } & \multicolumn{5}{|c|}{ Oolong Tea } \\
\hline & $\begin{array}{l}\text { Taiwan } \\
\text { (Tobit) }\end{array}$ & $\begin{array}{l}\text { China } \\
\text { (Tobit) } \\
\end{array}$ & $\begin{array}{c}\text { Premium } \\
(\mathrm{OLS}) \\
\end{array}$ & $\begin{array}{l}\text { Taiwan } \\
\text { (Tobit) }\end{array}$ & $\begin{array}{l}\text { China } \\
\text { (Tobit) } \\
\end{array}$ & $\begin{array}{c}\text { Vietnam } \\
\text { (Tobit) }\end{array}$ & $\begin{array}{c}\text { Premium1 } \\
\text { (OLS) }\end{array}$ & $\begin{array}{c}\text { Premium2 } \\
\text { (OLS) }\end{array}$ \\
\hline \multirow[t]{2}{*}{ AGE } & 0.16 & $1.02 * * *$ & $-0.54 * * *$ & 0.98 & $2.74 * * *$ & $1.75 * * *$ & $-1.39 * *$ & -0.66 \\
\hline & $(0.21)$ & $(0.22)$ & $(0.15)$ & $(0.63)$ & $(0.51)$ & $(0.44)$ & $(0.57)$ & $(0.48)$ \\
\hline \multirow[t]{2}{*}{ SEX } & $-10.11 * * *$ & 0.24 & $-11.10^{* * *}$ & 6.30 & -0.05 & 4.79 & 5.77 & 3.15 \\
\hline & (3.11) & (3.19) & $(2.26)$ & $(9.34)$ & (7.58) & $(6.52)$ & $(8.44)$ & $(7.16)$ \\
\hline \multirow[t]{2}{*}{ MAR } & $9.06^{*}$ & $18.93^{* * *}$ & -4.53 & 9.09 & $51.05^{* * *}$ & $18.42 *$ & $-36.75^{* * *}$ & -9.32 \\
\hline & $(4.64)$ & $(4.79)$ & (3.38) & (13.96) & (11.34) & $(9.73)$ & $(12.62)$ & $(10.70)$ \\
\hline \multirow[t]{2}{*}{ EDU1 } & $8.20 *$ & 5.08 & 2.82 & $34.93 * * *$ & 9.58 & 7.55 & $22.66^{*}$ & $25.08^{* *}$ \\
\hline & $(4.41)$ & $(4.48)$ & (3.22) & (12.94) & $(10.42)$ & (8.99) & (11.66) & $(9.89)$ \\
\hline \multirow[t]{2}{*}{ EDU3 } & -3.34 & -1.63 & -3.85 & $48.91 * * *$ & 0.17 & 10.44 & $45.62 * * *$ & $35.77 * * *$ \\
\hline & $(3.71)$ & (3.80) & (2.71) & (11.19) & (9.06) & $(7.82)$ & (10.11) & (8.57) \\
\hline \multirow[t]{2}{*}{ FAM10 } & 3.27 & 5.13 & 0.30 & $22.45^{* *}$ & 4.59 & 1.92 & $17.27^{* *}$ & $19.75^{* * *}$ \\
\hline & (3.22) & (3.30) & (2.35) & (9.58) & (7.75) & (6.67) & (8.66) & (7.35) \\
\hline \multirow[t]{2}{*}{$\mathrm{FE}$} & $-8.74 * * *$ & 1.26 & $-8.08^{* * *}$ & $-58.75^{* * *}$ & -5.17 & -9.05 & $-52.25 * * *$ & $-48.75^{* * *}$ \\
\hline & (3.34) & (3.40) & $(2.43)$ & (10.05) & $(8.12)$ & $(7.01)$ & (9.08) & $(7.70)$ \\
\hline \multirow[t]{2}{*}{ TINC } & $13.97 * * *$ & 5.74 & $8.74 * * *$ & $55.06^{* * *}$ & $37.43^{* * *}$ & $19.07^{* * *}$ & $17.91 *$ & $34.00^{* *}$ \\
\hline & (3.45) & (3.51) & $(2.52)$ & $(10.46)$ & (8.44) & (7.29) & $(9.45)$ & (8.01) \\
\hline \multirow[t]{2}{*}{ ZONE3 } & $16.97 * * *$ & $13.96^{* * *}$ & $3.48^{*}$ & $53.30 * * *$ & $39.65^{* * *}$ & $40.62 * * *$ & 12.28 & $13.18^{* *}$ \\
\hline & $(2.90)$ & (2.96) & (2.11) & (8.60) & (6.95) & (5.99) & $(7.77)$ & (6.59) \\
\hline \multirow[t]{2}{*}{ TRIAL1 } & -5.46 & -6.20 & -0.54 & $-35.77 * * *$ & $-17.34^{*}$ & -13.39 & $-19.12 *$ & $-22.91 * *$ \\
\hline & (3.91) & $(4.06)$ & $(2.86)$ & (11.80) & $(9.56)$ & $(8.21)$ & (10.63) & (9.02) \\
\hline \multirow[t]{2}{*}{ TRIAL4 } & -2.83 & -2.99 & 4.43E-03 & -11.92 & -4.33 & -2.24 & -7.53 & -9.89 \\
\hline & (3.92) & (3.96) & $(2.86)$ & (11.78) & $(9.50)$ & (8.20) & (10.63) & (9.02) \\
\hline \multirow[t]{2}{*}{ TASTE } & 3.18 & $13.22 * * *$ & $-7.11^{* * *}$ & $20.87 * *$ & $18.18^{* *}$ & -6.22 & 3.73 & $26.23 * * *$ \\
\hline & $(3.20)$ & (3.26) & (2.33) & $(9.62)$ & $(7.77)$ & (6.69) & $(8.68)$ & (7.36) \\
\hline R-squared & 0.22 & 0.25 & 0.20 & 0.30 & 0.25 & 0.23 & 0.25 & 0.29 \\
\hline $\mathrm{N}$ & 678 & 678 & 678 & 684 & 684 & 684 & 684 & 684 \\
\hline
\end{tabular}

Notes: The symbols***,** and $*$ denote that the variables are significant at a $1 \%, 5 \%$ and $10 \%$ level, respectively. Numbers in parentheses are estimated standard errors. Blank space indicates that the variable is not applicable. $\mathrm{N}$ is the number of observation. 
Table 8. Marginal Effects for Charcoal-Smoked Plum and Oolong Tea

\begin{tabular}{|c|c|c|c|c|c|c|}
\hline \multirow{2}{*}{ Variable } & \multirow{2}{*}{$\begin{array}{c}\text { Unit of } \\
\text { Measurement }\end{array}$} & \multicolumn{2}{|c|}{ Charcoal-Smoked Plum } & \multicolumn{3}{|c|}{ Oolong Tea } \\
\hline & & Taiwan & China & Taiwan & China & Vietnam \\
\hline BUYSP & 1 or 0 & 21.00 & 18.69 & - & _ & _ \\
\hline BUYTEA & 1 or 0 & - & - & 9.64 & -31.82 & -18.44 \\
\hline MARKET & 1 or 0 & -2.26 & -3.07 & -0.64 & 7.95 & 2.76 \\
\hline INFOF & 1 or 0 & 20.12 & 19.50 & -18.45 & 36.52 & 15.42 \\
\hline CHECK & 1 or 0 & -2.13 & -4.38 & 7.09 & 0.15 & -0.87 \\
\hline BUYIM & 1 or 0 & 9.90 & -5.23 & 137.75 & 57.25 & 35.88 \\
\hline PRICE & 1 or 0 & -10.29 & 0.06 & -25.76 & 1.80 & 5.14 \\
\hline FRESH & 1 or 0 & 0.05 & -12.84 & -44.85 & -15.81 & -32.82 \\
\hline PRFR & 1 or 0 & -5.03 & -2.27 & 0.82 & 22.35 & 19.49 \\
\hline PRSA & 1 or 0 & -0.37 & -1.48 & -6.23 & 3.90 & -4.33 \\
\hline PRCO & 1 or 0 & 8.10 & 7.88 & 2.03 & 25.04 & 8.56 \\
\hline FRSA & 1 or 0 & 0.59 & 4.65 & 8.39 & 14.27 & 12.27 \\
\hline LACOST & 1 or 0 & 8.97 & 10.34 & 10.05 & 7.12 & 1.64 \\
\hline RISK & 1 or 0 & -0.41 & -8.79 & 48.09 & 3.94 & 28.50 \\
\hline GOVFS & 1 or 0 & 0.42 & -3.42 & -0.31 & -16.57 & -15.58 \\
\hline AGE & Years & 0.15 & 0.81 & 0.93 & 2.44 & 1.58 \\
\hline SEX & 1 or 0 & -5.00 & 1.01 & 19.64 & 15.83 & 13.12 \\
\hline MAR & 1 or 0 & 8.88 & 7.02 & 21.26 & 23.39 & 17.32 \\
\hline EDU1 & 1 or 0 & -5.95 & -2.85 & -32.52 & -24.74 & -13.84 \\
\hline EDU3 & 1 or 0 & 0.24 & -2.91 & 53.00 & 22.75 & 16.30 \\
\hline FAM10 & 1 or 0 & 2.96 & 4.07 & 21.20 & 4.08 & 1.73 \\
\hline $\mathrm{FE}$ & 1 or 0 & 1.70 & 2.20 & -17.93 & 8.99 & 2.03 \\
\hline TINC & 1 or 0 & 8.21 & 2.01 & 63.36 & 29.55 & 23.48 \\
\hline ZONE3 & 1 or 0 & 17.90 & 15.16 & 57.31 & 45.01 & 41.98 \\
\hline TRIAL1 & 1 or 0 & -7.23 & -10.90 & -44.60 & -24.55 & -8.27 \\
\hline TRIAL4 & 1 or 0 & 0.64 & 4.76 & 7.62 & 8.77 & -2.75 \\
\hline TASTE & 1 or 0 & 4.74 & 11.54 & 28.22 & 20.39 & -1.96 \\
\hline
\end{tabular}


Table 9. Estimated Willingness to Pay and Premiums

\begin{tabular}{|c|c|c|c|c|c|c|c|c|c|}
\hline \multirow[b]{2}{*}{ Trial } & \multirow[b]{2}{*}{ Item } & \multicolumn{3}{|c|}{ Charcoal-Smoked Plum } & \multicolumn{5}{|c|}{ Oolong Tea } \\
\hline & & $\begin{array}{c}\text { Taiwan } \\
\text { (TW) }\end{array}$ & $\begin{array}{l}\text { China } \\
(\mathrm{CH})\end{array}$ & $\begin{array}{l}\text { Premium } \\
(\mathrm{TW}-\mathrm{CH})\end{array}$ & $\begin{array}{c}\text { Taiwan } \\
\text { (TW) }\end{array}$ & $\begin{array}{l}\text { China } \\
(\mathrm{CH})\end{array}$ & $\begin{array}{c}\text { Vietnam } \\
\text { (V) }\end{array}$ & $\begin{array}{l}\text { Premium1 } \\
\text { (TW-CH) }\end{array}$ & $\begin{array}{c}\text { Premium2 } \\
\text { (TW-V) }\end{array}$ \\
\hline \multirow{3}{*}{$\begin{array}{l}\text { Before } \\
\text { Tasting }\end{array}$} & $\begin{array}{l}\text { Mean } \\
(\mathrm{NT} \$)\end{array}$ & 54.07 & 30.21 & 24.84 & 212.9 & 113.33 & 113.24 & 105.84 & 105.9 \\
\hline & S.D. & $(17.12)$ & $(15.71)$ & $(8.48)$ & $(63.23)$ & $(41.40)$ & (34.92) & (44.29) & $(38.04)$ \\
\hline & $\begin{array}{c}\% \\
\text { Premium }\end{array}$ & & $79 \%$ & $83 \%$ & & $88 \%$ & $88 \%$ & $94 \%$ & $95 \%$ \\
\hline \multirow{3}{*}{$\begin{array}{c}\text { After } \\
\text { Tasting }\end{array}$} & $\begin{array}{l}\text { Mean } \\
(\mathrm{NT} \$)\end{array}$ & 57.41 & 42.13 & 22.46 & 239.62 & 133.47 & 110.72 & 115.59 & 133.88 \\
\hline & S.D. & (15.96) & $(17.47)$ & $(10.44)$ & $(63.75)$ & $(42.82)$ & (38.76) & (41.88) & (41.88) \\
\hline & $\begin{array}{c}\% \\
\text { Premium }\end{array}$ & & $36 \%$ & $54 \%$ & & $80 \%$ & $116 \%$ & $87 \%$ & $122 \%$ \\
\hline \multirow{3}{*}{ All Trials } & $\begin{array}{l}\text { Mean } \\
(\mathrm{NT} \$)\end{array}$ & 55.67 & 36 & 23.49 & 226.23 & 123.5 & 111.64 & 112.64 & 120.1 \\
\hline & S.D. & (16.08) & $(16.20)$ & (9.34) & $(63.79)$ & $(42.62)$ & $(34.87)$ & $(42.61)$ & $(41.27)$ \\
\hline & $\begin{array}{c}\% \\
\text { Premium }\end{array}$ & & $55 \%$ & $66 \%$ & & $83 \%$ & $103 \%$ & $92 \%$ & $109 \%$ \\
\hline $\mathrm{N}$ & & & 678 & & & & 684 & & \\
\hline
\end{tabular}

Notes: $\mathrm{N}$ is the number of the observations. TW, $\mathrm{CH}$ and V represent Taiwan, China and Vietnam. 


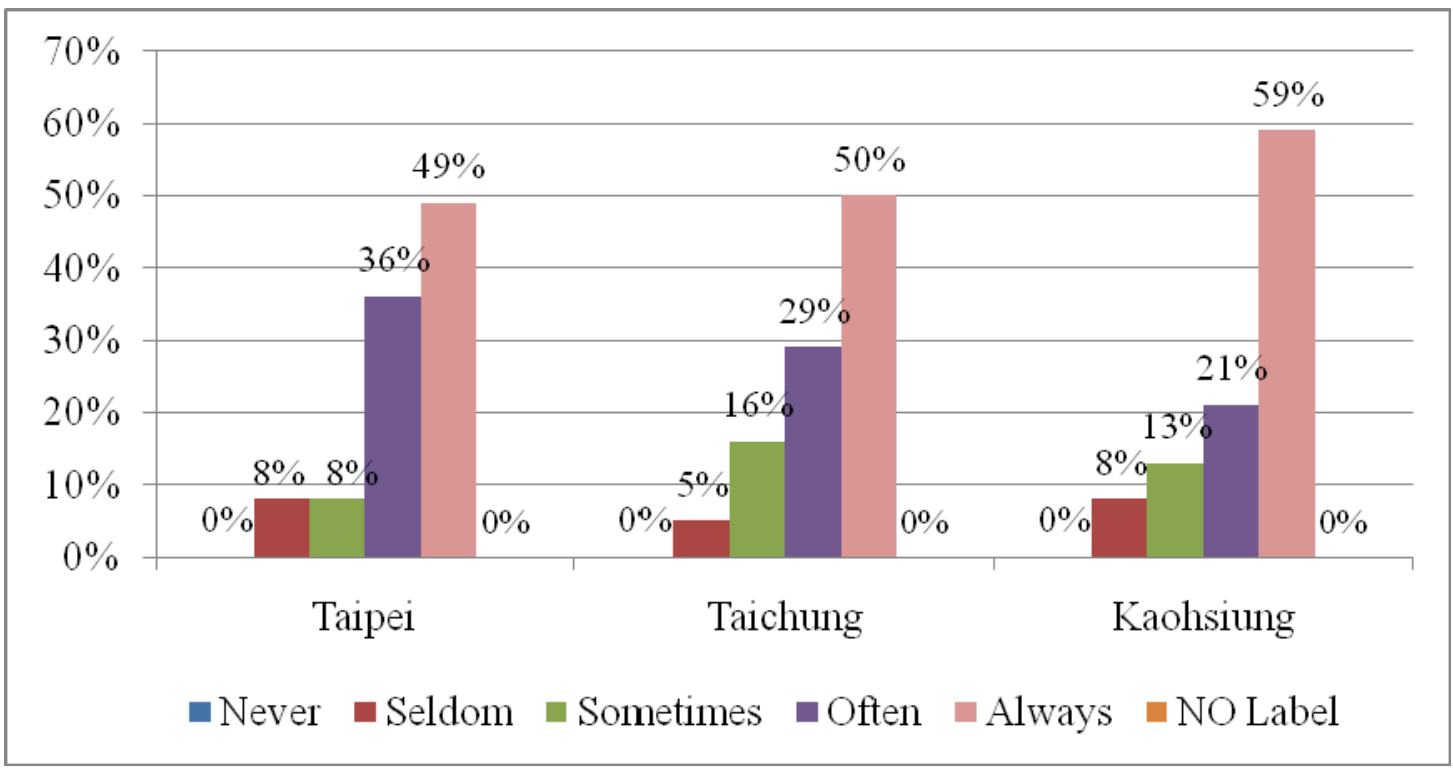

Figure 1. Distribution of Frequency on Checking Food Labels

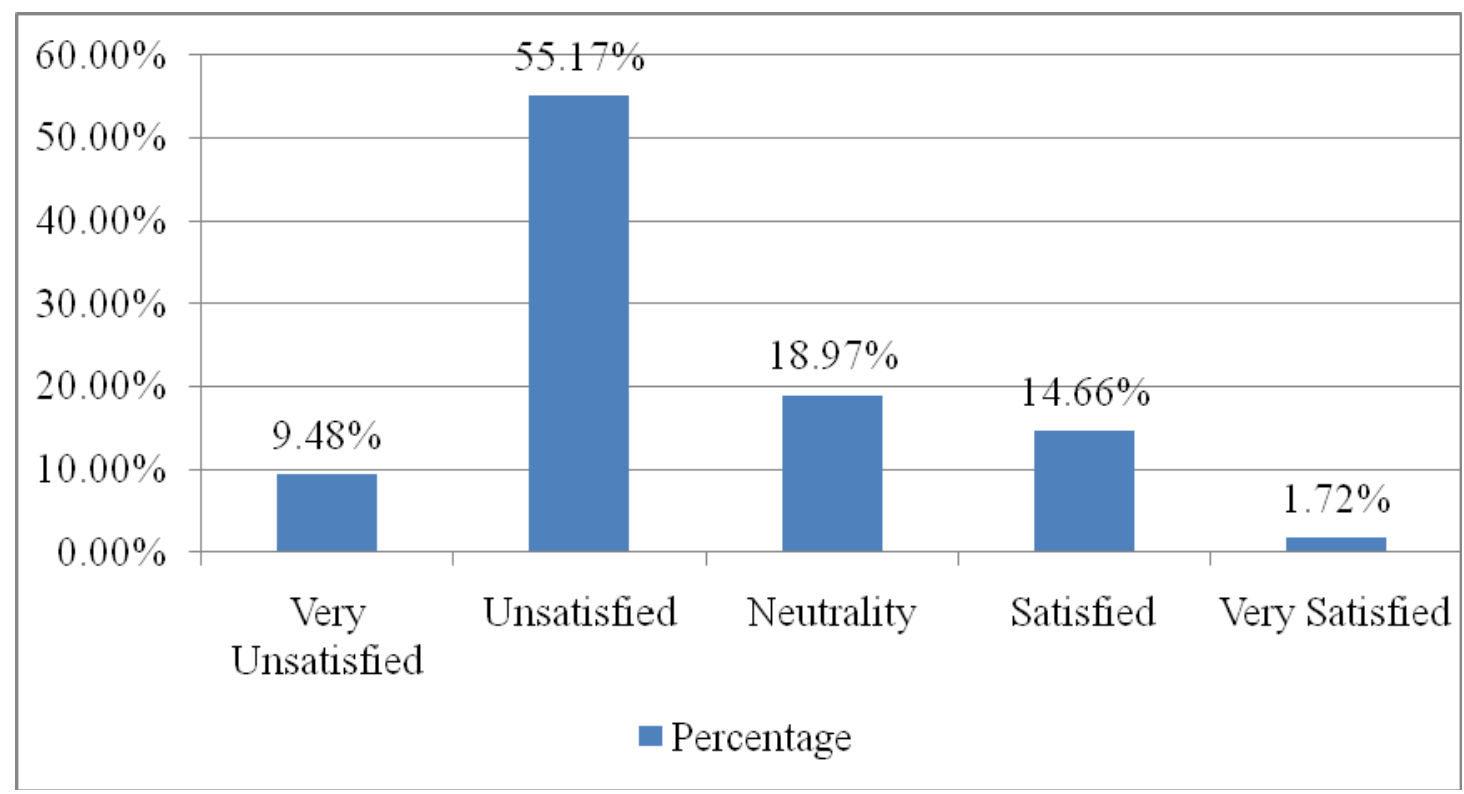

Figure 2. Distribution of Level of Satisfaction with Government on Food Safety Handling 